\title{
The Numerical Simulation Research on The Movement Rule of Rock Strata above The Coal Face with Shallow Buried Depth and Thin Bedrock
}

\author{
Guoli Wang \\ School of Resource and Safety Engineering \\ China University of Mining and Technology \\ Beijing, China \\ 3198026367@qq.com
}

Ruibin $\mathrm{He}$

School of Resource and Safety Engineering

China University of Mining and Technology

Beijing, China

371533545@qq.com

\author{
Yu Wang \\ School of Resource and Safety Engineering \\ China University of Mining and Technology \\ Beijing, China \\ 1227135978@qq.com

\section{Zhongzhong $\mathrm{Xu}$} \\ School of Resource and Safety Engineering \\ China University of Mining and Technology \\ Beijing, China \\ 1667292533@qq.com
}

\begin{abstract}
In order to acquire the rock strata movement rule above the coal face, which has shallow buried depth and thin bedrock, choosing the 201 dip working face of chang han gou coal mine, Shenhua group, as the engineering background. Using numerical simulation software UDEC, which has distinct elements, to do simulation analysis about the structure destruction rule of rock strata above working face and the sliding and unstable movement regularity of the main roof. This paper shows that the whole overlying rock strata of mining face falls by full thick and the ground subsides sharply when the first weighting of the main roof has happened. And with the advance of mining face, the overlying rock strata sinking phases. These simulated results are consistent with the field breakage of rock strata above the mining face. So the software UDEC can provide prospective theory basis for mining activities.
\end{abstract}

Keywords-shallow buried depth; thin bedrock; numerical simulation; rock strata caving; instability of the main roof

\section{INTRODUCTION}

A series of mining damage problems have happened in shallow buried coal seam mining in Shendong Mining Area, mainly include the roof caving, supports crushing, water and sand inrush and large-area land collapse, etc, which seriously affect the safe and efficient production. Roof falling accident is due to underground mining, which destroy the original balance of rock stress and lead to partial stress concentration within the rock. When the strength of redistributed stress is more than the strength of rock mass, the phenomenon of rock instability will occur. More serious accident that roof fall and rib spalling will happen if workers don't support timely and take correct supporting way[1 4]. Supports crushing is because the slow speed of working face advance and the large amount of roof subsidence, which make the support always in the high load condition and make preset values of safety valves differ widely. Further, the shear force imposed on support beam cover increases significantly[5 7]. Water and sand inrush accident in mining area mostly determined by special hydrogeological condition, including shallow buried depth, thin bedrock and loose covering layer that consisted of water[8 13]. These accidents have become the key issues that not only affect the safe and normal production of coal mine, but also fundamentally affect the resource recovery rate, output and benefit. However all these accidents are closely related to the rock movement rule caused by coal mining, therefore it's especially important to find out the movement rule of rock strata. Through simulated excavation of coal seam in the model, which handled by software UDEC, we can get an accurate prediction of the movement regularity of rock strata, so as to effectively optimize operation procedures, reinforce the management and put forward measures to prevent and avoid disasters.

\section{ENGINEERING BACKGROUND AND MODEL ESTABLISHMENT}

The 201 working face of chang han gou coal mine, Shenhua group, is a typical mining face with shallow buried depth and thin bedrock, which adopts inclined longwall mining method. Average thickness of the coal seam is $1.75 \mathrm{~m}$ and the dig angle is $1 \sim 3$ degrees. The immediate roof is mainly gray siltstone with an average thickness of $5.10 \mathrm{~m}$. The horizontal main roof is mainly mediumgrained sandstone including few fossil plants pieces. And the floor is mainly gray and hoary fine-grained sandstone, which constitute of mica, quartz and feldspar. Main bedding structure of the floor is wave. The land surface of 
mining area is vale and replat with bedrock exposed, which displays hilly landform character.

The process of coal mining is in three-dimensional space, but the graphic design software UDEC is twodimensional, so it's necessary to simplify the real situation. By using the numerical simulation method in dip profile of rock strata, we can get stress distribution and movement and deformation of rock strata around the working face during mining period. Firstly, choosing one section in inclination direction of working face and extracting coordinates on contour line of land surface through CAD software. Secondly, building model according to the actual coordinates, which really reflect the vale and replat on land surface.

The length of the model is $264 \mathrm{~m}$ and the height is $72 \mathrm{~m}$. Upper boundary of the model simulates the real land surface of vale and replat. The angle of rock strata is horizontal. And there is a slip line at the location of first roof weighting. Dividing the network into grids and assign physico-mechanical parameters to rock strata. The final model is established as Fig .1.

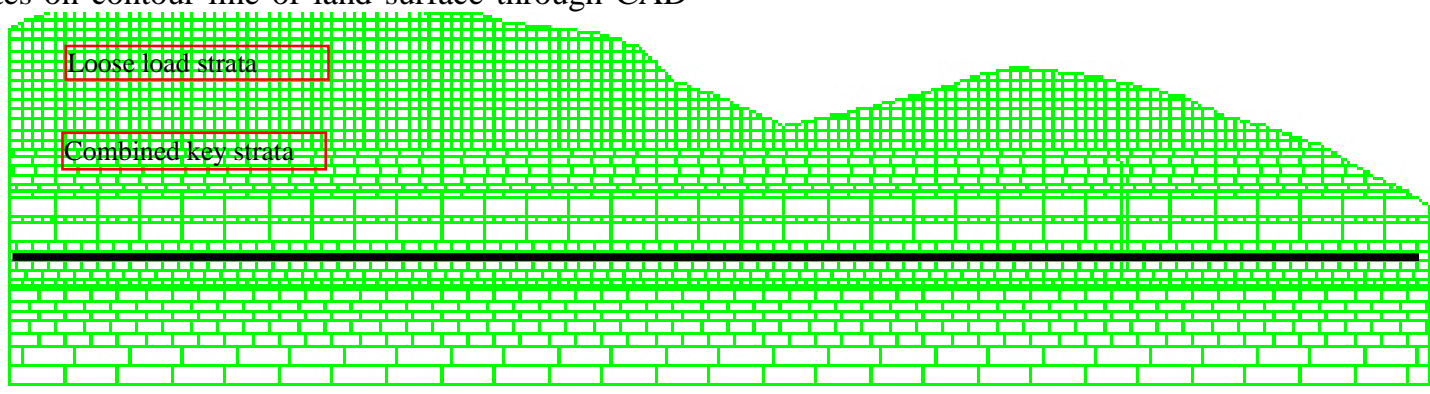

Figure 1. Model grid

Boundary conditions and initial conditions are imposed to model after all blocks cutting and all cells dividing. There is no load on the top surface of the model for it simulating the land surface directly. The top face only bears gravity and considers gravity gradient. Fixed boundary condition is adopted on the bottom and the left and right sides of the model[5] [7].

In order to track the stress distribution and sinkage of overlying rock strata and the deformation law of coal, observation point and observation line are laid out in the model after the design range is determined. Two observation lines are set in the model, respectively in the immediate roof and the main roof above the coal seam.

The physico-mechanical parameters measurement of coal and rock sample around the working face is completed in the lab. (see TABLE I)

TABLE I. ROCK PHYSIC-MECHANICAL PARAMETERS

\begin{tabular}{|c|c|c|c|c|c|c|}
\hline $\begin{array}{c}\text { Layer } \\
\text { number }\end{array}$ & Rock & Layer thickness/m & $\begin{array}{c}\text { Compressive } \\
\text { strength/MPa }\end{array}$ & $\begin{array}{c}\text { Elasticity } \\
\text { modulus/GPa }\end{array}$ & Cohesion/MPa & $\begin{array}{c}\text { Internal friction } \\
\text { angle } /\left({ }^{\circ}\right)\end{array}$ \\
\hline 1 & Weathered sandstone, gravel & 9.6 & 1.27 & & 0.11 & 10 \\
\hline 2 & Sandstone grit & 4.2 & 5.05 & & 1.52 & 35 \\
\hline 3 & Mudstone & 3.60 & 3.88 & 0.45 & 0.22 & 20 \\
\hline 4 & Fine sandstone & 3.40 & 15.54 & 2.99 & 1.45 & 30 \\
\hline 5 & Medium-grain sandstone & 5.80 & 29.9 & 2.85 & 2.18 & 35 \\
\hline 6 & Siltstone & 5.10 & 15.96 & 1.65 & 1.23 & 30 \\
\hline 7 & Mudstone & 0.80 & 5.64 & 0.41 & 0.22 & 20 \\
\hline 8 & coal & 1.75 & 18.43 & 1.61 & 0.54 & 18 \\
\hline 9 & Fine sandstone & 4.20 & 17.05 & 1.32 & 1.45 & 30 \\
\hline
\end{tabular}

III. THE ANALYSIS OF NUMERICAL SiMULATION RESULTS OF OVERLYING ROCK STRUCTURE BREAKAGE LAW

Excavation and calculation are made to the model and the open-off cut is located $40 \mathrm{~m}$ from right margin of the model for eliminating border effectiveness. The length of right-to-left excavation is $10 \mathrm{~m}$ every time until to $100 \mathrm{~m}$, which can achieve full mining of coal seam.

The distraction of overlying rock strata and $\mathrm{Y}$ displacement contour at caving $10 \mathrm{~m}, 20 \mathrm{~m}, 30 \mathrm{~m}, 40 \mathrm{~m}$, $80 \mathrm{~m}$ and $100 \mathrm{~m}$ are respectively shown in Fig .2 and Fig .3.

The 201 working face of chang han gou coal mine adopts all caving method to manage roof without stowing. When the simulated excavation advances $10 \mathrm{~m}(\mathrm{Fig} .2(\mathrm{a}))$, the immediate roof is fall but not the main roof. Supporting force of the support isn't big at this moment. The first weighting has occurred when the simulated excavation advances $20 \mathrm{~m}$ (Fig .2(b)), and the main roof begins to move down with slipping and instability appeared in the per-set sliding surface. The destruction in the main roof extended to land surface at this point. Corresponding to Y-displacement counter we could see that the displacement of the whole overlying strata is columnar when the simulated excavation advances $10 \mathrm{~m}$ (Fig .3(a)). That's to say the displacement of rock strata just occur within certain realms. The land surface is destructive and loose layer move down along fault line of the main roof when the working face advances $20 \mathrm{~m}$ (Fig .3(b)). In practice of coal mining we find that the supporting force of hydraulic support peaks at first time when the working face advances approximately $20 \mathrm{~m}$ by monitoring. Because the land surface is a slope, the support have the trend along the diagonal direction. All these simulated results are fit to real observations. 


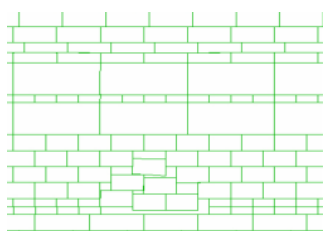

(a) $10 \mathrm{~m}$

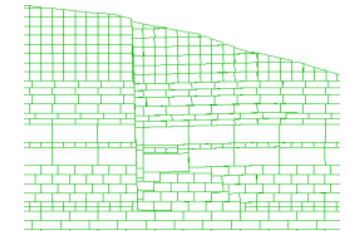

(b) $20 \mathrm{~m}$

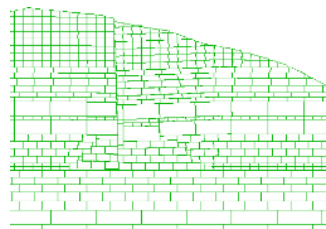

(c) $30 \mathrm{~m}$

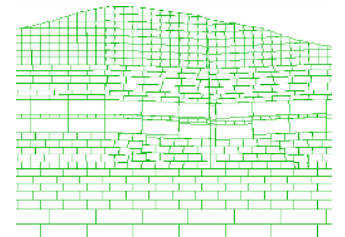

(d) $40 \mathrm{~m}$

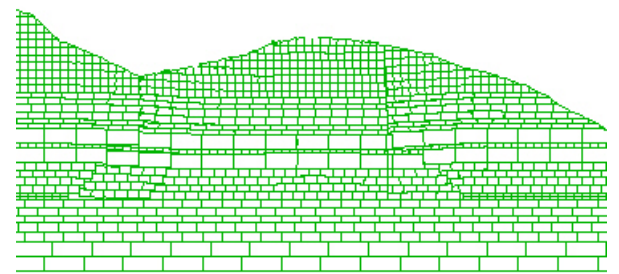

(e) $80 \mathrm{~m}$

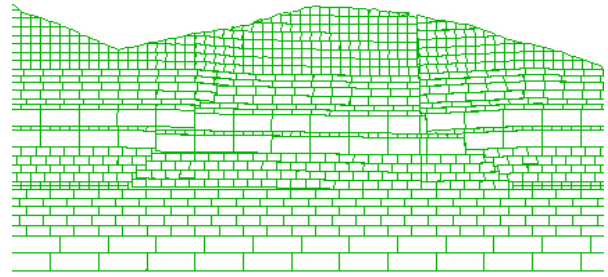

(f) $100 \mathrm{~m}$

Figure 2. The distraction of overlying rock strata at caving $10 \mathrm{~m}, 20 \mathrm{~m}, 30 \mathrm{~m}, 40 \mathrm{~m}, 80 \mathrm{~m}$ and $100 \mathrm{~m}$

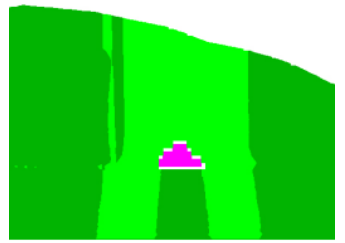

(a) $10 \mathrm{~m}$

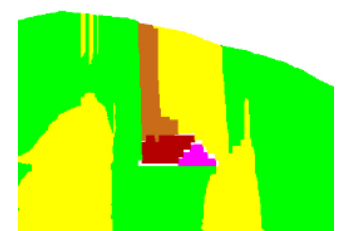

(b) $20 \mathrm{~m}$

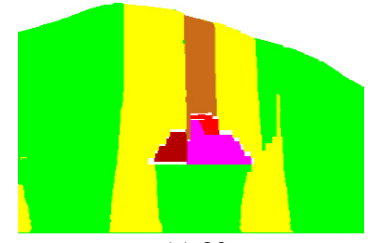

(c) $30 \mathrm{~m}$

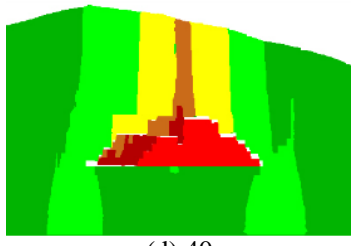

(d) $40 \mathrm{~m}$

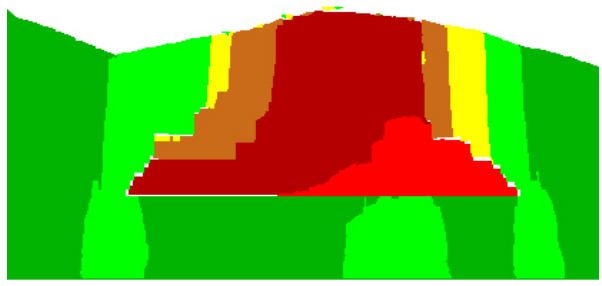

(e) $80 \mathrm{~m}$

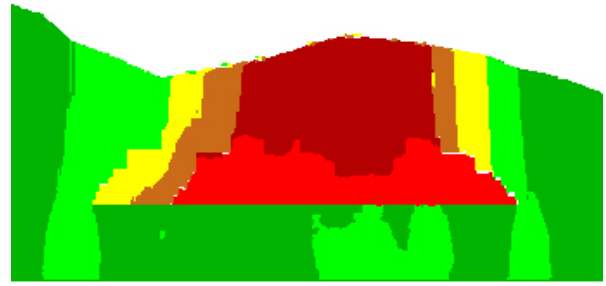

(f) $100 \mathrm{~m}$

Figure 3. Y-displacement contour at caving $10 \mathrm{~m}, 20 \mathrm{~m}, 30 \mathrm{~m}, 40 \mathrm{~m}, 80 \mathrm{~m}$ and $100 \mathrm{~m}$

When the simulated excavation advances $30 \mathrm{~m}$ (Fig .2(c)), the immediate roof is fully caving, but the main roof doesn' $t$ show mew slipping except for tiny strata separation. These prove that the main roof has the process of self-supporting instead of fall by full thick immediately when the first periodic weighting occurs[12] [13]. The main roof has a full-thickness caving and the destruction extends to land surface when the simulated excavation advances $40 \mathrm{~m}$ (Fig .2(d)). From Fig .3(c) and Fig .3(d) we can obviously see that the whole overlying rock strata is sectional sinking and forming a number of rock pillars. In practice, the ground also appears stepped subsidence and several cracks.

When the simulated excavation advances $80 \mathrm{~m}$ (Fig .2(e)) and 100m(Fig .2(f)), the whole overlying rock strata is caved fully in the range of $20 \mathrm{~m}$ behind working face. Fig .3(e) and Fig .3(f) show that the slip and cave of the overlying rock strata lags behind working face. Fig .3(f) also indicates that the cave of the main roof is irregular when the simulated excavation advances $100 \mathrm{~m}$.

\section{THE ANALYSIS OF NUMERICAL SIMULATION RESUlTS OF THE MAIN ROOF SLIDING AND UNSTABLE MOVEMENT REGULARITY}

Importing the displacement in vertical direction of the observation line, which set in the main roof, into excel document(shown as Fig .4). There will be first weighting and periodic weighting with the advancing of the working face. And analysing the vertical displacement of the main roof at the moment of first weighting and periodic weighting, we can summarize the breakage mode of the sliding and unstable main roof.

According to Fig .4, we can get the subsidence displacement curve of first weighting(advancing $20 \mathrm{~m}$, Fig .4(a)) and periodic weighting(advancing 30m, 40m; Fig .4(b), (c)) of the main roof. Fig .4(a) shows the first rupture of the main roof in the per-set sliding surface and the maximum settlement is $0.75 \mathrm{~m}$. When the working face advances $30 \mathrm{~m}$ (Fig .4(b)), the sinkage of the main roof increases significantly and the maximum settlement reaches to $1.80 \mathrm{~m}$. However, when the working face advances $40 \mathrm{~m}$ (Fig .4(c)), the maximum settlement has no significant change and the subsidence range becomes obviously larger. The sinkage of the main roof gradually increases from the mining face to the goaf, which leads to stepped subsidence on the ground. There is a stepped subsidence curve of the main roof displacement, because the small displacement from the key layer rotation. While the rotation turning to a certain extent, the whole main roof will break and there will be a stepped subsidence curve. All these phenomena are in line with the ground destruction through field monitoring. That's to say the failure mode of the main roof above the working face is stepped, in the condition of shallow buried depth and thin 
bedrock, and fracture width is related to the periodic weighting distance[8] [13].

From the Fig .4 we can draw that the supporting force of hydraulic support reaches the maximum at a location behind the working face and the support should have big compression quantity at this point. In addition, the supporting force and the compression of support gradually increase from mining face to this location. All these have been verified in practice.

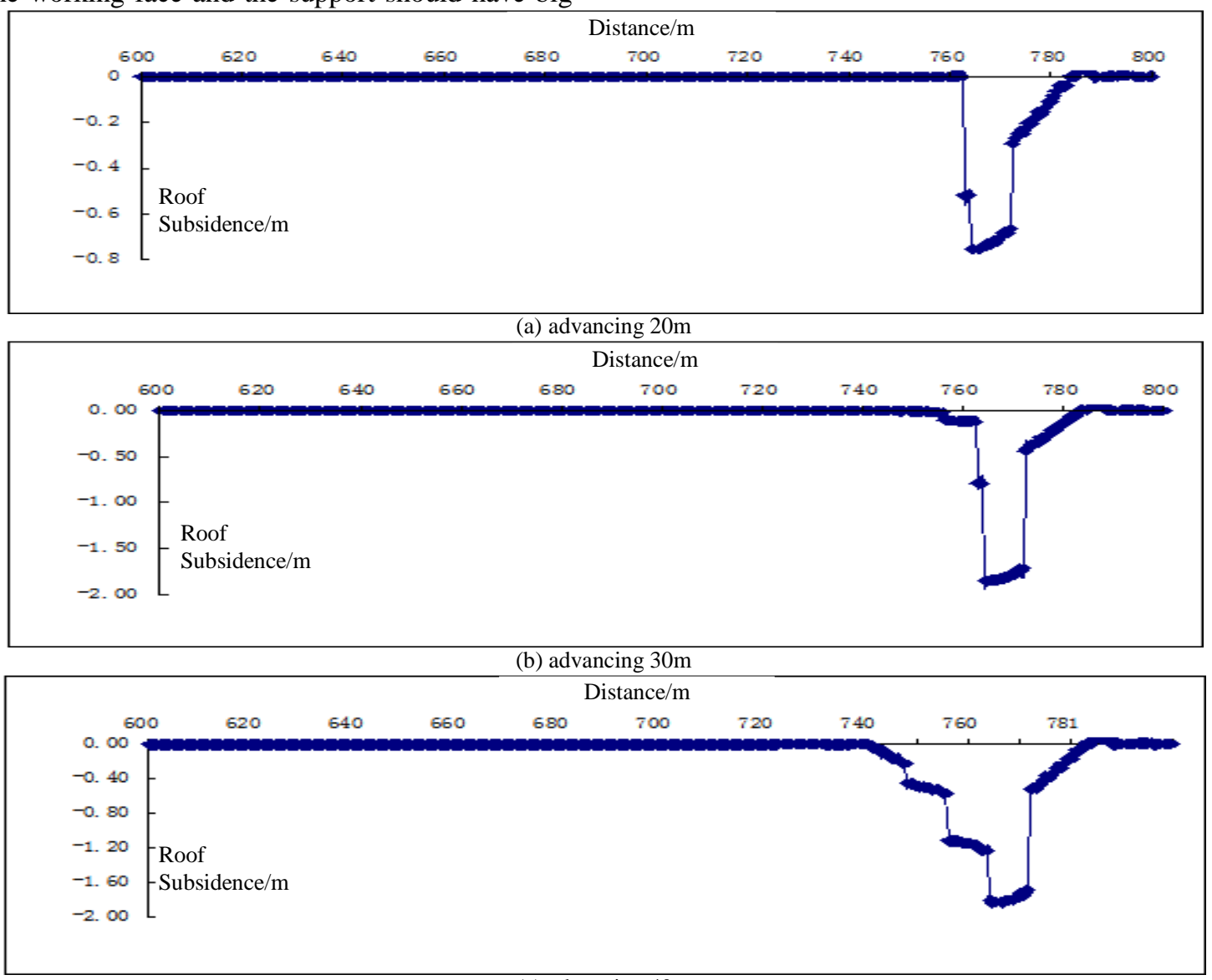

(c) advancing $40 \mathrm{~m}$

Figure 4. Y-displacement curve of combinational key strata

\section{CONCLUSION}

1) After the simulated excavation of the model, we can get that the main roof breaks along the per-set sliding surface, in the condition of shallow buried depth, and the whole overlying rock strata falls by full thickness. In addition, the ground subsides sharply and there are several opening cracks along the slipping surface. With the advancing of the working face, the overlying rock strata appears phased settlement destruction and the distance of destruction is related to the pace of periodic weighting. When the mining face advances approximately $80 \mathrm{~m}$, the settlement of ground reaches the maximum.

2) Through the use of simulation software UDEC, which has distinct elements, and modeling analysis, we can get pressure manifestation rule of the mining face. And the rule is consistent with field observations. So using the results, which come from simulating the real situation, to guide the actual mining activity has certain feasibility and reliability.

\section{REFERENCES}

[1] Liu Hongtao, Ma Nianjie, Zhao Feihu, Liu Fengming, "New bolting structure of fractured roof based on the Bossinesq equations[J]," Mining Science and Technology, 2010.
[2] Ju Jinfeng, Xu Jialin, Zhu Weibing, Wang Lujun, "Supports crushing mechanism on the goaf side of close distance coal seams in Shendong Mining Area[J]," Chinese Journal of Rock Mechanics and Engineering, 2013.

[3] Ju Jinfeng, Xu Jialin, "Preventive countermeasures of supports crushing in the mining of shallow buried and close distance coal seams[J]," Chinese Journal of Mining and Safety Engineering, 2013.

[4] Ya Peng, Feng Wulin, "The research on water and sand inrush disaster with shallow buried depth in Dongsheng Mining Area[J]," Coal Science and Technology, 2002.

[5] Li Fengyi, "Strata movement rule due to shallow longwall mining and the research on safety margin of mining[D]," PhD Dissertation, Liaoning Project Technology University, 2007.

[6] Chen Yi, "Research on rock movement rule above the shallow coal seam with thin and weakly caking bedrock and research on support resistance," Master Degree Thesis, Henan Polytechnic University, 2010

[7] Hou Zhongjie, Huang Qingxiang, "Mining simulation of shallow buried coal seam with thin bedrock and loose layer[J]," Shanxi Coal Technology, February 1994, pp.38-41.

[8] Holla L, Buizen M, "Strata movement due to shallow longwall mining and the effect on ground permeability[J]," Aus IMM Bullefin and proceeding, Vol.295 No.1, 1990

[9] Singh R P, Yadav R N, "Subsidence due to coal mining in India[M]," Proceedings of the 1995 5th International Symposium on land subsidence, IAHS Publication, No.234, 1995. 
[10] Rajendra Singh T N, Bharaf B.Dhar, "Coal pillar loading in shallow conditions. International Journal of Rock Mechanics and Mining Sciences and Geo Mechanics Abstract," 1995.

[11] Lin Xinyuan, Chen Peihua, "Research on pressure manifestation rule due to shallow mining with very soft roof[J]," Chinese Journal of Rock Mechanics and Engineering, 2004.
[12] Qian Minggao, Miao Xiexing, Xu Jialin, "Research on key strata theory within rock controlling[J]," Journal of China Coal Society, 1996, pp.225-230.

[13] Qian Minggao, Liu Tingcheng, "Ground Pressure and Its Control[M]," Beijing: Coal Industry Publishing House, 1991. 